\title{
The Theoretical Origins of the Legal Regimes of Land Rights in Nigeria
}

\author{
Anugbum Onuoha \\ Faculty of Law, Rivers State University, Port Harcourt, Nigeria
}

\begin{abstract}
This article traced the theoretical origins of the legal regime of the current land rights in Nigeria. It argues that the configuration of the federal system of government is influenced by institutional theory which has systematically evolved from the era of colonisation backed by the unstable national affinity to the modernisation theory. Both theoretical pivots have given false hope of developing a prosperous national economy that wholly rely on investment in crude oil which required unwavering control of lands. The article posits that, the current state of affair with regards to land use, land ownership rights and the unitary control of land through coercive legislation is consistent with the suggestions of the dependency theory. Therefore, that Nigeria's land laws have evolved to a point of increased uncertainty of tenure for private and communal entities. The article further highlights the deeprooted effects of institutional capture flowing from the theoretical origin of Nigeria's laws and policy formulations on infrastructure including land rights. In conclusion, this article excavated the paradoxes of the laws governing land use and land ownership rights in Nigeria by emphasizing that the true nature and effects of the extant land laws in the country should be evaluated based on its functions and not its form, hence to understand and correct the defectiveness of the land laws, there should be detachment from the false normative expectations about institutional appearance.
\end{abstract}

Keywords: Land, Laws, Dependency, Institutional Theory, Institutional Capture.

JEL Classifications: B15, B52, K11, K23, Q15, Q24.

DOI: $10.7176 / \mathrm{JLPG} / 97-08$

Publication date:May $31^{\text {st }} 2020$

\section{Introduction}

To effectively provide the theoretical origin of Nigeria's land laws, it is crucial to first highlight the land rights consist of bundle of privileges and legal control that are possessed by the land owner. Hence, Ricardo, ${ }^{1}$ Mill $^{2}$ and Smith $^{3}$ accentuated that land has irreplaceable potentials, dissimilar from capital and labour, therefore is extremely important on the crescendos of production. The importance of land requires efficient legal protection which every country is obligated to preserve.

The effectiveness of the legal framework of a country can be evaluated under different yardsticks. At the centre of such evaluation is the extent to which individual rights and safety are best preserved. Therefore, the legal system cannot be completely assessed without aligning it to the practicality and implications on private properties. Laws that are enacted to preserved and protect a country expected to clearly define rules, uphold rational enforcement and consistent with workable economic models that supports social system. It is against the settings of the preservation of property rights and the enforcement of rules that regulate rational use of scarce resources that several theoretical foundations of law and economics emerged to sustain the various sources of laws of different nations, for example, the natural rights theorists are of the view that private market exchange and private property rights are natural rights that are integral in nature.

It is the concepts of private market exchange and private property rights which is the foundation of land reform. It is argued that land reform is the main constituent of expansion strategies of land laws. Therefore, the popularity of land reforms in law and economics reflects on the "diversity of beliefs regarding its positive impact on productive efficiency, distributional equity, political, social, and economic structures." ${ }^{4}$ Simply put, the leading law and economics argument has emphasized the combined efficiency and equity effects of law on land governance. $^{5}$

There are flurry of law and economic theories, however, the focus of this paper is to trace the theoretical routes of the current land use regime in Nigeria and how the affinity to the theories are shaping Nigeria's legal setting with regards to land ownership and land use. The driveway of this discourse is to rehearse Ho's ${ }^{6}$ observation

\footnotetext{
${ }^{1}$ David Ricardo (18 April 1772 - 11 September 1823

${ }^{2}$ John Stuart Mill (1806-73)

${ }^{3}$ Adam Smith (1723 - 1790)

${ }^{4}$ Feder Gershon; Feeny David; Feder, Gershon Feeny, David. Land tenure and property rights: Theory and implications for development policy. The World Bank economic review. -- Vol. 5, no. 1 (January 1991), pp.135-153.

${ }^{6}$ Peter Ho. An endogenous theory of property rights: opening the black box of institutions, The Journal of Peasant Studies (2016) 43:6, 11211144, DOI: $10.1080 / 03066150.2016 .1253560$
} 
as follows:

From a neo-liberal paradigm, secure, formal and private property rights are crucial to foster sustained development. From this follows that institutions that fail to respond to shifting socio-economic opportunities are pushed to new arrangements. The enigma is posed by developments on the ground. Why would the removal of authoritarian institutions during the Arab Spring or Iraq war not increase market efficiency but rather cause the reverse, while China and India, despite persisting insecure, informal and common institutions, featured sustained growth? This collection posits that understanding these paradoxes requires a refocusing from form to function, detached from normative assumptions about institutional appearance. ${ }^{1}$

The neo-liberal theorists derived strength from natural law theory. For example, Smith ${ }^{2}$ idea of natural law was based on the premise of free and self-regulating action whereby everyone in a society is allowed to scrutinise his own legal and economic actions, which should be able to make the most of the output of his capacity. Accordingly, liberty of action should be able to foster individual productivity, increase societal wealth and advancement. Therefore, there is no need for the intervention of government in lands, private industry and commerce, because natural laws are greater than statutory laws because the laws of nature are just and morally correct.

Smith's ${ }^{3}$ model was based on the 'laissez-faire principle' which entails that the governments or rulers are not to enact laws that places constraint on the liberty and freedom of private individuals with regards to the control, use and ownership of property. In essence, that socio-economic progress involves savings, division of labour and free market. Nonetheless, that "there is a set of rules or rights of justice and perhaps even of morality in general which are, or may be known by all men by hello either or reason or of a moral sense, and which possesses an authority superior to that of such commands of human sovereigns and such customary legal and moral regulations as may contravene them." Smith's model is widely ignored in the capitalist circles. In order to facilitate the understanding of the theoretical origin Nigeria's current legal regime with regards to land ownership and land rights it vital to undertake a brief review of relevant literatures.

\section{Literature Review}

The literatures herein are of the law and economics school of thought which essentially discusses land and land rights as essential criteria for national development. Coase ${ }^{4}$ observed that the efficiency in the allocation of property is the basis of conflict reduction in the society. He argued that, property rights are deep rooted in human existence hence, when conflict arise concerning the violation of property rights, law alone may not be able to address and resolve the conflicts. Coase therefore explains that the only perfect solution to property rights conflict is founded in the bargaining model which involves the conflicting parties. Simply put, when parties engage in bargain rather than litigations, there is the possibility of a social efficient outcome irrespective of which the parties is the legal rights owner.

Coase further explains that the transaction cost of bargain can be negligible compared to settlement through litigation. In essence, he argued that: "If trade in an externality is possible and there are no transaction costs, bargaining will lead to an efficient outcome regardless of the initial allocation of property rights." In summary, Coase puts forward a bargaining model by which law establishing land ownership should exist alongside a transaction model for resolving conflicts arising from interference with ownership and use of property. The model hangs largely on a well-defined system of law that respects and preserves private ownership of lands. It postulates that the rights that flow from land should not be detached by the enactment of legislation. By the same token, Alchian and Demsetz ${ }^{6}$ explained that:

\footnotetext{
${ }^{1}$ Peter Ho went on to say that: "In so doing, three things are accomplished. First, starting from case studies on land, it is ascertained that the argument can be meaningfully extended to labor, capital and beyond. Second, the argument validates the 'credibility thesis' - that is, once institutions persist, they fulfill a function. Third, the collection studies 'development, broadly construed', by including the modes of production and beyond, the rural and urban, the developed and developing. This is why it reviews property rights from China to India, and from Mexico to Malaysia, covering issues such as customary rights, mining and pastoralism, but also state-owned banks, trade unions and notaries."

2 [n. 5]

${ }^{3}$ Ibid

${ }^{4}$ Ronald H. Coase. "The Nature of the Firm". Economica (1937) 4 (16): 386-405.

${ }^{5}$ Ronald H. Coase The Problem of Social Cost". Journal of Law and Economics. 3 (1): 1-44

${ }^{6}$ Armen Alchian and Harold Demsetz. The Property Right Paradigm. The Journal of Economic History, 1973, vol. 33, issue 1, 16-27. They also explained that: "To "own land" usually means to have the right to till (or not to till) the soil, to mine the soil, to offer those rights for sale, etc., but not to have the right to throw soil at a pas-- serby, to use it to change the course of a stream, or to force someone to buy it. What are owned are socially recognized rights of action. The strength with which rights are owned can be defined by the extent to which an owner's decision about how a resource will be used actually determines the use. If the probability is "1" that an owner's choice of how a particular right should be exercised actually dominates the decision process that governs actual use, then that owner can be said to own absolutely the particular right under consideration. For example, a person may have an absolute right to pick apples off a tree, but not to prune the tree."
} 
We frequently speak of someone owning this land, that house, or these bonds. This conversational style undoubtedly is economical from the viewpoint of quick communication, but it masks the variety and complexity of the ownership relationship. What is owned are rights to use resources, including one's body and mind, and these rights are always circumscribed, often by the prohibition of certain actions.

According to the above quotations, Alchian and Demsetz emphasizes that private ownership of land is an illusion because individuals only possess the "socially-structured rights to use something [land] in certain ways." Therefore, if a person claim to own a piece of land, actually what he own is the right to use it or alienate the rights to another consequently, the power of private land ownership is purely the possibility that what he need to do with the land can be done. This implies that the legal and social arrangement of land rights have social significances.

Demset $z^{2}$ adopted the neoclassical law and economics framework in his analysis of land rights and concluded that three criteria must exist for the efficient sustenance of land rights namely: (a) Transferability which implies that property must retain the features of being able to be allocated from low to high value uses; (b) Universality which implies that scarce resources are owned by individuals; (c) Exclusivity which implies that property rights should retain exclusive rights. Demsetz further contended that the allocation of property rights is the main precondition that must be accomplished prior to the distribution of defined asset values. This is because a welldefined property price is required to replicate fundamental demand and supply settings and to simplify socially cherished exchange among monetary agents. Needham, ${ }^{3}$ observed that:

Property rights are a social creation. Each society regulates, by a combination of formal legislation, common law and custom, what counts as an item of property, and how that item may be used. What is regulated is both how the state arbitrates in the property relationship between two or more private persons and how the state may intervene in the exercise of private property rights. The result is called the 'property rights regime' in that society. This is often the subject of intense political debate, as it has both social and economic outcomes.

Livingston $^{4}$ and Libecap 5 are in agreement on the view that property rights and the propelling institutions are decided by way of political manipulations. The manipulations are undertaken through bargains among the members of the interest groups which adopts several game theory approach of politicisation to reach consensus. They however, observed that most of the political procedures used in determining and enforcing property rights are obtained through questionable and contentious models which negatively affects the allocation of resources. They also explained that, despite the erroneous believe that the state intervention in property allocation is better to serve public interest, the allocative efficiency creates conflicts and dangerous to the institutional sustenance. Libecap ${ }^{6}$ contends that allocation skirmishes, and the ways and means of resolving the conflicts, are likely to obstruct positive and equitable dynamic of the governance institutions therefore, impact on the property rights planning. Libecap ${ }^{7}$ basis of analysis appear to support the institutional theory of law and economics which acknowledges the importance of well-defined property rights. Nonetheless, Libecap concluded amongst others that, the institutional challenges in allocating property rights becomes more complicated with the increasing size of the competing interest groups. This is because it becomes difficult to balance the interest of all private and collective parties in the process of apportioning the property rights. It is the competing interest that breed conflicts which ultimately affects institutional changes.

Kim and Mahoney ${ }^{8}$ explained that property rights are essential and integral parts of the overall social institutions which delineate the collection of rights allowed to private individuals of precise natural resources including but not limited to lands. Consequently, private ownership of the natural resources often comprise of a diversity of land rights, such as "the right to exclude non-owners from access, the right to appropriate the stream of economic rents from use of and investments in the resource, and the rights to sell or otherwise transfer the resource to others." Kim and Mahoney ${ }^{9}$ are proponents and wholly motivated by the institutional theory of law

\footnotetext{
${ }^{1}$ See: Joseph T. Mahoney. Economic Foundations of Strategy, New York: Sage, 2005, p.120

${ }^{2}$ H. Demsetz. Towards a theory of property rights. American Economic Review (1967) 57 pp.347-359.

3 D.B. Needham, Property Rights, in International Encyclopedia of the Social \& Behavioural Sciences, 2001. Online at: https://www.sciencedirect.com/topics/social-sciences/right-to-property accessed 11 April 2020.

${ }^{4}$ Marie Leigh Livingston: A Review of Gary D. Libecap. Contracting for Property Rights. Journal of Economic Issues Vol. 25, No. 1 (Mar., 1991), pp. 283-285

${ }^{5}$ Gary D. Libecap. Contracting for Property Rights. Cambridge: Cambridge University Press. 1989.

${ }^{6}$ Ibid

${ }^{7}$ Ibid

${ }^{8} \mathrm{~J}$. Kim \& J T Mahoney. Property rights theory, transaction costs theory, and agency theory: An organizational economics approach to strategic management. Managerial and Decision Economics. 2005 Jul 1; 26 (4):223-242. https://oi.org/10.1002/mde.1218

${ }^{9}$ Ibid
} 
and economics hence, they observed that, "property rights institutions range from formal arrangements, including constitutional provisions, statutes, and judicial rulings, to informal conventions and customs regarding the allocations and uses of property. Such institutions critically affect decision making regarding resource use and, hence, affect economic behaviour and economic performance."

In the same perspective, North ${ }^{2}$ investigated the effects of national institutions on the economic, legal and social development. He went further to highlight the features of the theory of institutional change. He found that the past inspires the contemporary and the future. North also observed that the past attributes of an institution rarely alters rather it accrues therefore that, institutional changes over a time-lag may affect the choices and decisions of policy makers but such decisions may not really be different from the fundamental nature of the institution in that, decisions of an institution often align with "the nature of path dependencies." North went further to discuss the role of establishments and the ways by which they interrelate with the national and international institutions. Thus, contends that the nature of "incremental institutional change, together with the imperfect way by which decision makers interpret their environment and make choices, accounts for path dependencies and makes history relevant." 3 This analysis will be made clearer by undertaking a discussion on the institutional theory and how it shapes the extent land legislation in Nigeria.

\section{Institutional Theory and Nigeria's Land Use Act}

Scott ${ }^{4}$ suggests that there is no generic and global definition of institution. He explains that institutions are social arrangements that have developed to powerful and recognised level. In essence, institutions comprise of a variety of "cultural-cognitive, normative, and regulative elements that, together with associated activities and resources, provide stability and meaning to social life. Institutions are transmitted by various types of carriers, including symbolic systems, relational systems, routines, and artefacts." 5 Therefore, institutional theory is concerned with the analysis of policies, procedures and the official and legal features of governmental organisations.

In the words of North, ${ }^{6}$ institutions are "humanly devised constraints that structure political, economic and social interactions," spanning from all the official written and unwritten rules including the "constitutions, laws, judicial rulings, property rights - to informal restraints and rewards--sanctions, customs, traditions, codes of conduct. Unless impeded by transaction costs, which are the costs of defining, enforcing, and trading property rights [and] those institutions that are out of step with potential economic gains are adjusted through bargaining among relevant agents." 7 Similarly, North ${ }^{8}$ opined that the "modern economic growth results from the development of institutions that permit an economy to realize the gains from specialization and division of labour associated with the sophisticated technology that has developed in the Western world in the last several centuries."

According to Mahoney, "Rulers devised property rights in their own vested interests, and transaction costs resulted in typically inefficient property rights prevailing. As a result, it was possible to account for the widespread existence of property rights throughout history (and in the present) that did not produce economic growth." It is against this background that it is foreseeable that rulers do formulate policies, rules and laws to further their interest. ${ }^{10}$ Those interests are propelled through organisations and institutions hence, the need to evaluate the institutional theory and the resulting influence on property rights in Nigeria.

Institutional theory submits that the institutional structure of a country is a reflection of its total effectiveness thus, a faulty institutional structure of a country inevitably affects the whole social, political, and economic system. The worth of the collective structure of an institution regulates the efficiency of all the components and interface of the society and where the institutional survival is frequently challenged by outside powers that overwhelm its development, the institution gradually weakens in strength and becomes hazardously insecure. ${ }^{11}$

Weber $^{12}$ suggests that there are several variables within the social structure of the society that combine to

\footnotetext{
${ }^{1}$ The same view was upheld by Daniel H. Cole and Peter Z. Grossman. The Meaning of Property Rights: Law versus Economics? Vol. 78, No. 3 (Aug., 2002), pp. 317-330

${ }^{2}$ D. North. Institutions, Institutional Change, and Economic Performance (Chapter 1: An introduction to institutions and institutional change). Cambridge University Press, New York, 1990) 3-10.

${ }^{3}$ Adapted from J. Kim \& J T Mahoney [n. 21]

${ }^{4}$ W. R. Scott. Institutions and Organizations. Thousand Oaks, CA: Sage, 1995, p. 235

${ }^{5}$ W. R. Scott. Institutional carriers: Reviewing modes of transporting ideas over time and space and considering their consequences," Industrial and Corporate Change, 2003, 12: 879-94. Scott also observed that: "Institutions operate at different levels of jurisdiction, from the world system to localized interpersonal relationships. Institutions by definition connote stability but are subject to change processes, both incremental and discontinuous."

${ }^{6}$ D. C North. Structure and Change in Economic History. New York: Norton, 1981, p. 36

${ }^{7}$ Ibid

${ }^{8}$ D. C North. Institutions, Transaction Costs, and Economic Growth. 1987, Economic Inquiry 25: 419-428, at p. 422

${ }^{9}$ Joseph T. Mahoney. Economic Foundations of Strategy, New York: Sage, 2005, p.120

${ }^{10}$ W. R Scott. Institutional theory: Contributing to a theoretical research program. In K. G. Smith, \& M. A. Hitt, (Eds.), Great minds in management: The process of theory development. Oxford: Oxford University Press, 2004, pp. 460-484

${ }^{11}$ Lynne G Zucker. "Where do institutional patterns come from? Organizations as actors in social systems." In Institutional Patterns and Organizations; Culture and Environment, 1988, 23-49, Lynne G. Zucker, ed. Cambridge, MA: Ballinger.

${ }^{12}$ Maximilian Carl Emil Weber (1864 - 1920) German sociologist and political economist
} 
support or challenge the institution. He listed laws, norms, regulations and all other social routines which can develop along normative platforms to develop and become the established indexes for gauging the socially acceptable activities. Institutional theory offers explanation on how the amalgamated variables of the society is formed, distributed, endorsed, and enthralled in time and space. It also offer explanations on how the variables decline. Thus, it provides lucidity on the concept of "stability and order in social life"1 and, elucidates the "need for the understanding of "consensus, conformity; conflict and change in social structures."

In view of the touchy the subject-matter of land use and land ownership in Nigeria, it is hereby suggested that the Land Use Act which is Nigeria's foremost land legislation derives its origin from three main theoretical strands namely: The institutional theory, the dependency theory and the modernisation theory. Nigeria as a country is yoked into the configuration of federalism. Therefore, it is a federal nation-state. The federal institutional framework and its impact on the land use and land ownership cannot be separated from the influence flowing from the external environment which consistently shapes and determine the existence of the national politics.

As earlier stated, the structure and behaviour of Nigeria's federal institution and the sub-institutions are routinely being shaped by the internal and external factors. The internal interfaces include widespread corruption, assortment of ethnic and cultural conflicts and intrinsic traditional totalitarianism at native governance levels. The internal dynamics are deployed by the external elements to produce coercive legal frameworks.

The external factors are predominantly the foreign powers which influences governance and laws through the foreign direct investment, social and economic aid packages, training of policy makers and military assistance. It is the external factors that creates the eagerness for continuous dependency of the national institutional frameworks. The over dependence on the powerful foreign variables that has rendered the federal institution weak and vulnerable hence, the institution does not appear to meet the basic criteria of a true federalism. The universally recognised six criteria of true federalism are: "Adaptability, complexity, autonomy, congruence, exclusivity and coherence." ${ }^{3}$

Kingston ${ }^{4}$ explained that, "the adaptability element is about the ability of an institution to adjust to innovation within the global and home environment and its ability to influence the environment for the benefits of the internal elements." Furthermore, 'complexity' is concerned with the competence of the institution to shape respectable internal arrangements adept in accomplishing necessary objectives for the benefits of the elements within the structure. 'Autonomy' is the ability of the institution to formulate responsible policies and enforce its own laws autonomously without the need for external supports. 'Congruency' is the ability of an institution to preserve operative connections among all the social subdivisions and the political subsets within the entire structure. ${ }^{6}$ 'Exclusivity' is the capacity to retain all the criteria of independence and sovereign entity. ${ }^{7}$ According to Kingston,

Sovereignty is not just about political independence and geographically defined boundary. It stretches into the inquiry into the extent to which an institution can survive independent of external control. Simply put, sovereignty is the capability of the institution to maintain itself as an exclusive entity without competing subsets (within the unit) and without external domination and influences, thus, a country that depends largely on external sources of financial and social support cannot be entirely sovereign. 'Coherence' is the capability of the institution to control its own affairs and to develop ways of handling the internal elements without infringing on basic and fundamental rights."

Federalism as an institution and as a structure of government is appropriate for integration and unification of several subsets of a nation and for the neutralisation of conflicts among the varied ethnic and sectional origins within a country in such ways that the multiplicities become treasured resources of the country instead of yielding resentments. Therefore, federalism as an institution is supposed to involve equitable sharing of power and resources between the centre and the periphery.

The current federal institution revolves around minimal power sharing relative to three crucial areas: territory, politics and economics. The 1999 Nigeria Constitution vest most of the powers in the central government including the power to enact laws, decrees and regulations in vast areas

\footnotetext{
${ }^{1}$ W.R Scott. Institutional Theory: Contributing to a Theoretical Research Program, in Great Minds in Management: The Process of Theory Development, Ken G. Smith and Michael A. Hitt, eds. Oxford UK: Oxford University Press, 2004.

${ }^{2}$ Ibid

${ }^{3}$ Kato Gogo Kingston. Pollution and Environmental Responsibility in Petroleum Extraction in the Niger Delta of Nigeria: Modelling the Coase

Theorem. (Lambert Academic Publishing, 2017, at p. 181

${ }^{4}$ Ibid

${ }^{5}$ Ibid

${ }^{6}$ Ibid

${ }^{7}$ Ibid
} 
including defence, commerce, national revenue control, and policing. Though some of the powers of the central government and those of the States overlap, the central government encroaches on the powers of the States and where conflict arise, the centre has the veto power. In essence, the States in Nigeria does not have autonomous control over any aspects of governance. ${ }^{1}$

The federal institution was installed in 1914 by the British as the engine of amalgamation to neutralise the customary land tenure system was the main system of land ownership and land dealings that were in different parts of the territories that became known as Nigeria in $1914 .^{2}$ The standard of cultural beliefs and traditions were stringently recognised ${ }^{3}$ and followed by the natives of the communities and observed as revered. The declaration of the Land Use Decree in 1978 by the Military Regime, reflects the major weakness in the federal institution in that, it needs foreign supports in cash and several other sectors to propel the economy. This being the case, land became a trading point for foreign direct investment in crude oil and natural gas. The pre-existed customary land tenure system did not favour the handing over of lands to foreign investors without encumbrances therefore, the federal institution had to make a law that provided the foreign oil corporations to gain unrestricted access to crude oil lands in Nigeria. In addition to the enactment of the Land Use Decree (which later became known as the Land Use Act), section 44(3) 1999 Constitution FRN (as amended) states inter alia:

.... entire property in and control of all minerals, mineral oils and natural gas in under or upon any land in Nigeria or in, under or upon the territorial waters and the Exclusive Economic zone of Nigeria shall rest in the Government of the Federation and shall be managed in such manner as may be prescribed by the National Assembly.

To further illustrate that the weak federal institution quest for foreign capital is the underpinning objectives for the enactment of coercive land legislation, we can draw attention to the provision of section 2(1) Exclusive Economic Zone Act 1978 provides that:

.... sovereignty and exclusive rights with respect to the of exploration and exploitation of the natural resources of the seabed, subsoil and superjacent waters of the Exclusive economic Zone shall vest in the Federal Republic of Nigeria and such rights shall be exercised by the Federal Government ...

Similarly, section 1 of the Petroleum Act ${ }^{4}$ provides inter alia: "... to the effect that the entire ownership and control of all petroleum in, under or upon any lands, including and covered by water) which is: (a) is in Nigeria or (b) is under the territorial waters of Nigeria, (c) forms part of the continental shelf; or (d) forms part of the Exclusive Economic Zone of Nigeria."

The foregoing discussion entrenches the effects on porous federal institution to the extent that its sole dependence on crude oil spurs it to enact coercive laws with regard to land use and land rights. This dependence is better understood in the analysis of the dependency theory.

\section{Dependency Theory and Nigeria's Land Use Act}

According to Ferraro, ${ }^{5}$ dependency theory gathered momentum the 1950 s through the help of Raul Prebisch who at the time was the director of the United Nations Economic Commission for Latin America. Prebisch and his compatriots were worried by the obvious reality that economic growths in the developed countries did not trigger economic development in the third world nations. Prebisch and his compatriots undertook some studies and found that the economic activities of the wealthier countries habitually result in economic woes in the developing countries of Africa, South America and Asia. Their findings were at divergence from those of the neoclassical theory, which rumoured that economic development has no boundaries, therefore, that every country shared equality of economic and social growth - Pareto equilibrium. Ferraro ${ }^{6}$ added that:

Marxists theorists viewed the persistent poverty as a consequence of capitalist exploitation. And a new body of thought, called the world systems approach, argued that the poverty was a direct consequence of the evolution of the international political economy into a fairly rigid division of labor which favored the rich and penalized the poor.

Nonetheless, dependency theory argues that the economic development of a country cannot be actualised where such a country excessively rely on foreign capital in that, foreign capital comes with severe consequences

\footnotetext{
${ }^{1}$ Kingston [n. 37] 182-3

${ }^{2}$ Emeka Egburuonu, How to Handle Land Cases in Practice (Basic Rights Publication Ltd.2001)

${ }^{3}$ R. W James, Nigerian Land Use Act: Policy and Principles (Unife Press Ltd 1987)

${ }^{4}$ CAP P. 10 LFN 2004

${ }^{5}$ Vincent Ferraro, "Dependency Theory: An Introduction," in the Development Economics Reader, ed. Giorgio Secondi. London: Routledge, 2008, pp. 58-64

${ }^{6}$ Ibid
} 
including the external interference with the laws and institutions of the host nations. Kingston ${ }^{1}$ suggested that, "dependency theory tries to assess and discuss the nature of third world underdevelopment by evaluating the models of relations occurring between countries and how the relationships result in inequalities among the interacting countries."

Dependency theorists further contend that the world poorest countries are routinely dispossessed of their rightful remunerations of the profits of their lands, causing loss of land rights and poor standards of living. This creates dilemma and complications that are difficult to address by the government of the developing countries. For instance, one of the leading arguments for the enactment of the Land Use Act in Nigeria was that, it will remove the customary land tenure system which hindered foreign investment across all sectors especially the extractive industries. Therefore, it was anticipated that, the influx of foreign direct investment into Nigeria would foster economic growth and transfer of technical skills for the overall growth of Nigeria. The belief was based on the doctrines of the modernisation theory. However, the developing countries including Nigeria, despite enacting coercive land laws to foster foreign direct investments has not record significant economic growths since the Land Use Act was enacted in 1978. This is partially because Nigeria is weaker partners in the global capitalist economy. Changes can only occur in the legal. social, cultural, political and economic systems of the developing countries when leaders of the developing countries are able to design and devise ways and means of sustaining their development without external influences. ${ }^{2}$

\section{Conclusion and Policy Implications}

This paper conjures the ontological ${ }^{3}$ assumptions that every law flow from at least one theoretical origin hence, that some extant laws in Nigeria, specifically, the Land Use Act which regulates land use and land tenure in the country derived its origin from the unpopular remnants of the institutional theory and heavily coated by the dependency theory which is the reason for the deviation of the law from the normative basis of customary principles of equity and justice.

The paper has shown that the effects and influence of theoretical links cannot be excluded from the dialogues of Nigeria's property law erudition. The central argument of therefore, is that, it is the defectiveness of the federal institution alongside the weak nature of the sub-national institutions that created fear of self-reliance which led to the dependency on external supports and, the external support system has captured the institutional prowess to such extent that, the federal institution has no choice but to enact legislation that best serve the interest of the external interveners hence, the enactment of the Land Use Act.

It is further contended that the prevailing land use system in Nigeria has eliminated the customary property rights by suppressing private ownership of lands in perpetuity. This is consistent with the postulation of the institutional theory which emphasised that:

So conventional is the identification of institutionalism and property, ironically that some disciplines tend to treat property as requiring no particular analysis. That repose has recently been disrupted by the growing influence of institutional economists on global development policies, particularly through the International Monetary Fund and other lending agencies. These agencies have maintained, often in a rigid, non-empirical way. ${ }^{4}$

The policy implications of this paper is directional in the sense that, it highlight the dangers of over-reliance on external supports and external capital as it interrupts the laws of the host nations. Nigeria should devise the means of self-sustenance by internalising the profits of her current investment to such extent that it cannot be compelled by the external environments alter or degrade her laws especially, the laws relating to property use and property ownership.

The very boundaries of modern property systems seem to be shifting beyond the nation state system, that incorporation decisions will necessarily involve significant normative choices, and that some traditional systems may simply be inconsistent with the institutional ontology of modern [legal and]

\footnotetext{
${ }^{1}$ Adapted from Kingston [n. 37]. Kingston further quoted Ferraro inter alia: "Dependency is ... historical condition which shapes a certain structure of the world economy such that it favours some countries to the detriment of others and limits the development possibilities of the subordinate economics... a situation in which the economy of a certain group of countries is conditioned by the development and expansion of another economy, to which their own is subjected."

${ }^{2}$ Kingston [n. 37] 185

${ }^{3}$ According to Crotty, 'ontology' is defined as "the study of being". It is concerned with "what kind of world we are investigating, with the nature of existence, with the structure of reality ..." in M. Crotty, The Foundations of Social Research: Meaning and Perspectives in the Research Process, London: Sage Publications, 2003, $3^{\text {rd }}$ edition, 10.

${ }^{4}$ Errol Meidinger. Property Law for Development Policy and Institutional Theory: Problems of Structure, Choice, and Change. Buffalo Legal Studies Research Paper Series, Paper No. 2006-001
} 
economic institutions. ${ }^{1}$

Institutions are gradually preserved as themes of scrutiny, and not as simple offshoots of other variables. Institutions are distinctive, hitherto imperative and sturdy. Property is an integral aspect of institutional discourse.

${ }^{1}$ Errol Meidinger. Property Law for Development Policy and Institutional Theory: Problems of Structure, Choice, and Change. Buffalo Legal Studies Research Paper Series, Paper No. 2006-001 